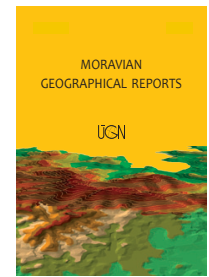

MORAVIAN GEOGRAPHICAL REPORTS

\title{
Environmental factors influencing the distribution of agricultural terraces: Case study of Horný Tisovník, Slovakia
}

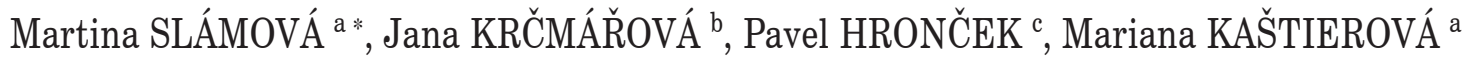

\begin{abstract}
The cadastral district of Horný Tisounik represents a traditionally managed Carpathian mountain agricultural landscape with extensive terraces. It was historically governed by two counties with different feudal economic systems - agricultural and industrial. This paper aims to enrich traditional methods in environmental history. We applied geospatial statistics and multivariate data analysis for the assessment of environmental factors influencing the distribution of agricultural terraces. Using linear models, the hypothesis was tested that the terrace distribution is functionally related to selected factors (affiliation to the historic counties; average altitude and slope; distance from water, buildings and settlements; units of natural potential vegetation; and current land use). Significantly greater amounts of terraces were located in the agricultural county compared to the industrial county. A principal component analysis showed the coincidence between the current agricultural land use and higher concentrations of terraces occurring in lower altitudes, closer to settlements and buildings, and within the unit of Carpathian oak-hornbeam forests. These findings regarding the most significant factors influencing the distribution of terraces are used in proposals for incentives to improve the management of the traditional agricultural landscape.
\end{abstract}

Keywords: agricultural terraces, traditional landscapes, environmental history, multivariate analysis, Slovakia

Article history: Received 4 January 2016; Accepted 20 December 2016; Published 31 March 2017

\section{Introduction}

Landscapes rich in agrobiodiversity are often the product of complex farming systems that have developed in response to the unique physical conditions of a given location, as well as to cultural and social influences (Altieri, 1999). Traditional agricultural landscapes (TALs), characterised by a complex stratified palimpsest of patterned human activity through time, are physical records of agriculture, risk management strategies, building technology, environmental change and historical ecology (Ericson, 2003). Agricultural terraces are valued from the cultural and historical viewpoints as specific features of TALs (Špulerová and Petrovič, 2011).

The terraced field is the most frequent landform that developed after contour ploughing (Stankoviansky, 2001). Terraced slopes have long formed integral elements of Mediterranean landscapes. To northern Europeans, such a landscape often evokes romantic and idyllic images. In reality, however, these landscapes are better perceived as human responses to a harsh and demanding environment
(Rolé, 2007). Agricultural terraces in Slovakia form a relevant part of agricultural history, yet their function in the traditional agricultural landscape, as well as their conservation, is under-researched. There are official policy documents that focus to some extent on TALs (Špulerová and Petrovič, 2011), and in 2005 Slovakia adopted the European Landscape Convention (CoE, 2000), which proclaimed the preservation and the maintenance of the characteristic Slovakian landscape types. TALs, however, are not subject to any specific national protection policy (Slámová et al., 2013), even though they do represent a significant part of a Slovakian landscape typology.

Terrace soils are distinctive features of the agricultural landscape in Europe. A considerable number of papers on terraced systems and soils were reviewed, with a focus on Southern Europe. A complete inventory of terraced areas is not available, however, and the total terraced surface is therefore unknown (Stanchi et al., 2012). Terraces deserve considerable research investment to understand how

\footnotetext{
${ }^{a}$ Department of Landscape Planning and Design, Faculty of Ecology and Environmental Sciences, Technical University in Zvolen, Slovakia (*corresponding author: M. Slámová, e-mail: mslamova@hotmail.com)

${ }^{\mathrm{b}}$ Institute of Ethnology, The Czech Academy of Sciences, Czech Republic.

c Department of Geo and Mining Tourism, Faculty of Mining, Ecology, Process Control and Geotechnology, Institute of Earth Resources, Technical University of Košice, Slovakia
} 
different historical and environmental contexts affected their cycles of construction, use and abandonment (Bevan et al., 2013). Comprehensive studies on agricultural landscapes with terraces, interpreting their context with respect to the natural environment, including human interactions, however, have appeared in the last ten years in Slovakia (Lieskovský et al., 2014; Lieskovský et al., 2015).

This article aims to examine the historical and natural factors influencing the distribution of terraces in a Slovakian case study area. In this context, we present the implementation of methodologies from landscape ecology into the field of environmental history. Environmental history is a relatively new scientific field, which has developed recently in Slovakia (Holec, 2014; Hronček, 2014). Classic works of earlier environmental historians often lacked scientific credibility, as traditional historians interpreted a history mainly from written materials and such an approach has its limits in the reconstruction of many of the most interesting aspects of past environmental relations (Lewis, 2014). Today, environmental history seeks to incorporate new approaches to previous methodologies. In this article, geospatial and statistical analysis are employed in exploring the context among terraces and several examined factors.

\section{Objectives of the research}

The main aim of this article is to assess the impact of various environmental factors on the establishment and distribution of relict agricultural terraces in the study area in light of their historical genesis. Interest from researchers in this topic has increased in recent decades. For example, McCane et al. (2010), Fall et al. (2012) and Quintus et al., (2015) have reported results on relationships among terraces and settlements. Agnoletti et al. (2015) evaluated the influence of natural factors on terraces, while Bevan et al. (2013) used a broad-spectrum approach. In this work, we focused on the assessment of relationships among terraces and selected factors from natural and human environments using multivariate analysis.

We selected and tested environmental factors which could hypothetically influence the distribution of terraces in the cadastral district of Horný Tisovník. The following factors were chosen on the basis of previously published works and also the characteristics of the study area: a) affiliation to the historic counties of Divín or Modrý Kameň; b) average altitude; c) average slope; d) distance from water; e) distance from buildings and settlements; f) natural potential vegetation (Carpathian oak-hornbeam forest, submountainous beech forest or beech and fir-beech forest); and g) current land use (forests classified as 'JPRL' - units of the spatial division of forests' and 'OLP' - 'other wooded land'; agricultural land)

The National Forest Centre (Slovakia) (NFC) specified both forests categories for the purpose of forest management planning and Slovak acronyms were applied in the article. 'OLP' units correspond with agricultural land overgrown with a forest which still has not been classified as a forest bearing productive and protective functions (NFC, 2015).

The cadastral district was historically governed by two counties with different feudal economic systems - agricultural and industrial. Affiliation to the historic counties was interpreted according to known literature (Balasa, 1960). We assumed that different economic systems influenced terrace distribution in the countryside. Hypothetically, an agriculturally-based county would prefer agricultural land with terraces on gentle slopes; at lower altitudes, terraces would be found predominantly in the southern part of the county. Similar research has been conducted by de Blois et al. (2001): models of relationships among determinants of vegetation cover in two agro-forested landscapes that had differed by some environmental factors and historic land use, confirmed the dominant effect of historical factors on vegetation patterns.

Further, we tested terrace distances from water and settlements in order to show that positive relationships would be expected in the study area according to known data from previous research conducted in similar traditionallyused agricultural areas in Slovakia (Lieskovský et al., 2015). A south-north geo-climatic gradient, combined with ascending altitude (from the south to the north of the cadastral district), could hypothetically affect the establishment the terraces in the study area: hence, an examination of terrace distribution within units of natural potential vegetation was carried out. Generally, soil types are considered to be a relevant agronomic factor in an agricultural survey. In the case of the study area, we did not examine the relationship between soil types and terraces, as cambisols and cultisoils prevail and no specific influence of soil types on terrace distribution would be expected.

\section{Study area of Horný Tisovník}

TALs cover an area of 56,068 ha of Slovakia, which is $11.43 \%$ of the total area $\left(49,035 \mathrm{~km}^{2}\right.$ ) (data from Atlas of the Slovak Republic, Miklós and Hrčiarová, 2002). Terraces are typical forms of landscape mosaic of the traditional agrarian ("plough land - meadow - grazing") landscape archetype in Slovakia. They have persisted predominantly in marginal agricultural sub-mountainous and mountainous areas, and, even there, only locally (Hreško et al., 2010).

The cadastral district of Horný Tisovník is located in the Western Carpathian Mountains in central Slovakia: almost half of the agricultural land is traditionally managed (Fig. 1) and an extensive terrace system spreads on the slopes of the mountains. It lies in the region of the Central Slovakian Neovolcanites where andesitic and pyroclastic rocks prevail. Tuffs and tuffites occur locally. Slightly fertile, slightly deep and deep modal cambisols, and neutral-to-acid cultisols spread over the terraces in the study area. Rankers and pseudogleyic cambisols occurred only locally (Miklós and Hrnčiarová, 2002)

The district is divided into western and eastern parts by the Tisovník water course. This stream also formed the administrative boundary between two former counties of the district: Modrý Kameň and Divín (Fig. 1). The first interactions between a human population and the landscape are assumed to have been established in the Middle Bronze Age (1500 to 1200 BCE) near Bralo Hill (723 $\mathrm{m}$ a.s.l.) (Balasa, 1960). During the $14^{\text {th }}$ and $15^{\text {th }}$ centuries, settlement in the mountainous areas of northern and central Slovakia, including the Tisovník district, was supplemented by shepherds of Romanian and Ruthenian origin in a process known as the Wallachian colonisation. Over the next century, the colonisation expanded to the west and the bearer of it was then the Slovak population (Špulerová et al., 2014).

The first written record of the villages of Dolný Tisovník and Horný Tisovník dates back to the year 1548. After 


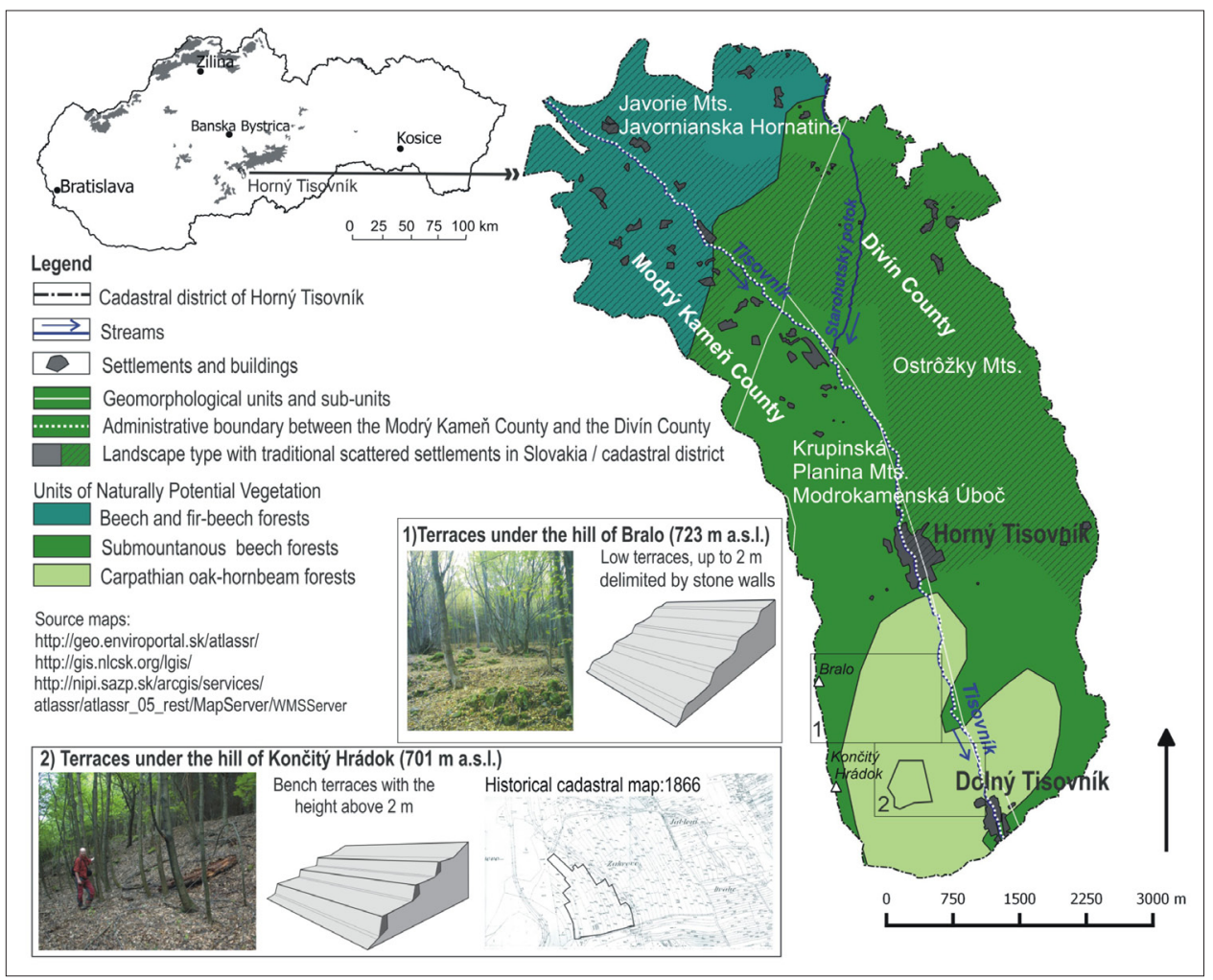

Fig. 1: Traditional agricultural landscapes, natural and historical units and boundaries of the study area Source: Compiled by authors

that date, the study area was divided into counties and terrace farming was established ${ }^{1}$. Scattered settlements were formed concurrently with terrace farming activities, beginning in the $16^{\text {th }}$ century in Modrý Kameň County, while pastoral and industrial activities prevailed in Divín County. The formerly dense natural forests were gradually cut down during the Balassa family administration from the $16^{\text {th }}$ to the $19^{\text {th }}$ centuries. A large part of the timber production was processed locally (sawmill, charcoal burning) or transported to the wider Hungarian Empire (Alberty et al., 1989). During the $19^{\text {th }}$ century, three glassworks were founded and the demand for wood increased. This is when the population peaked (Borovszky, 1911).

An unfavourable geographical position, with difficult access to the relevant residential and economic centres and communications, resulted in a cadastral district in the marginal regions (Horňák and Rochovská, 2007). In the studied district, extensive farming prevails; almost half $(48.19 \%)$ of the district $\left(31.17 \mathrm{~km}^{2}\right)$ is covered by a traditional agricultural landscape with scattered settlements (15.02 km²) (Miklós and Hrnčiarová, 2002).

According to existing typologies (Lasanta et al., 2013), we identified the following types of terraces in the field (2010):

1. terraces represented by small slope gradients that are delimited by herbaceous vegetation or a wall made from stones that were removed from cultivated fields (under Bralo Hill); and

2. bench terraces on higher slope gradients which are built up by stones (Končitý Hrádok Hill) (Fig. 1).

\section{Methods and data}

In the following sections, we describe: (i) the data collection procedures for the terraces still present in the study area and the comparison of terrace distributions between current and historical maps; and (ii) the process of data collection, multivariate analysis and correlations of the environmental factors influencing terrace distribution in the countryside.

Descriptive statistics were processed using a free and open source geographic information system (GIS), Quantum GIS (QGIS), version QGIS 2.8.3 Wien. Public raster maps were accessed by a QGIS web map server (WMS) client and selected data were digitised and saved as vector files. The coordinate reference system S-JTSK (Fero) /Krovak (EPSG code 2065) was applied in all maps.

Testing the influence of the chosen factors on terrace distribution (terrace length in a grid cell) encompassed the following steps: extracting the data from maps by QGIS 2.8.3 Wien; pre-processing data in MS Excel; correlation, analysis of variance (ANOVA), and linear regression analysis by the statistical discovery software JMP 7.0.1 for Windows (SAS, 2015); and visualisation of demonstrated relationships by RDA ordination using the licensed CANOCO for Windows 4.52 (Ter Braak and Šmilauer, 2003).

\subsection{Terraces data}

Varotto and Ferrarese (2008) provided the concept of new classification instruments for a comparative assessment of terraced landscapes within the European Interreg ALPTER project. In this article, we only applied basic parameters

\footnotetext{
${ }^{1}$ County is a historical territorial unit whose Slovak equivalent is "župa", respectively "stolica" as a territorial unit of the feudal government. Both historical territories had regional dimensions.In this paper we use the term county instead of a manor, although the examined areas (Modrý Kameň and Divín) represent territorial units at a lower administrative level (so called "panstvo").
} 
characterising the density of terraces. Our GIS survey on terraces limited data acquisition from publicly available maps. Thus, only basic geospatial parameters of the terraces were calculated and analysed: frequency $[\mathrm{n}]$; length $[\mathrm{km}]$, [percentage]; and density $\left[\mathrm{km} / \mathrm{km}^{2}\right]$. Terraces were digitised from topographic 'ZM' maps $(1: 10,000)$ provided by Geoportál (2015).

A visual comparison of the current land use of terraces and historical land use of terraces reported on maps of the second military mapping (1819-1827; 1837-1858) (SEA, 2015) was carried out in two localities where terraces were identified in the field (2010).

In the next steps, a terrace's length in a grid cell was used as an expression of terrace distribution and analysed as a dependent variable in linear models (analysis of variance, linear regression and multivariate analysis). Geospatial data about terrace length was estimated in a vector grid $(100 \times 100 \mathrm{~m})$ covering the whole study area. The grid was generated by QGIS Research Tool, Vector Grid. Raw GIS data were pre-processed in MS Excel 2010.

\subsection{Testing environmental factors}

(i) Affiliation to historic county: There were two possible affiliations in the Tisovník district: Modrý Kameň and Divín. Modrý Kameň County historically focused on crop production on agricultural terraces. On the other hand, in Divín County industrial production was preferred. Historic counties were digitised according to known archival sources (Martuliak, 2006) and vectorised.

(ii) Terrain (altitude and slope): Altitude as another tested factor has been shown by Dobrovodská (2006) to limit agriculture in several localities in the Carpathian Mountains in Slovakia. Slope steepness is considered to be not only a determinant for building terraces but also a crucial factor affecting terrace preservation and the preservation of traditional arable fields in general. Previous analyses showed that fields with slopes steeper than $11^{\circ}$ remained in small parcels and were not collectivised (Lieskovský et al., 2014). Terrain parameters such as the average slope $\left[^{\circ}\right]$ and the average altitude (absolute) [m a.s.l.] were derived from the digital terrain model (DTM) with a resolution $10 \times 10 \mathrm{~m}$ per pixel (DTM 3.5) using the Zonal statistics QGIS plugin. A DTM provides a bare earth representation of terrain or surface topography and it is a vector data set composed of regularly spaced points and natural features. DTM 3.5 was provided by The Geodesy, Cartography and Cadastre Authority of the Slovak Republic, under the license contract No. 55-11-2290/2015. The resolution of the DTM 3.5 corresponds with the resolution of topographic 'ZM' maps (1:10,000) (Geoportál, 2015), which were used for the vectorisation of terraces. Contour lines derived from the DTM 3.5 correspond with hypsographic data of 'ZBGIS' maps (Geoportál, 2015) which are currently the most accurate maps in Slovakia.

(iii) Distance from watercourses, settlements and buildings: The geological substrate of neovolcanic formations (prevailing in the study area) constitutes poor conditions for surface water accumulation. Thus, the distance of terraces from watercourses is considered to be a limiting factor for their establishment in the study area. Distance from settlements can be a factor in terrace foundation as well as their preservation. Lieskovský et al. (2015) characterised distances of terraces from settlements as an important factor for their preservation in the case of TAL with dispersed settlements and TAL with arable land and grasslands.
Distances of terraces from watercourses, settlements and buildings were calculated within buffer zones with a regular interval of $100 \mathrm{~m}$ using QGIS plugin Multi Ring Buffer. Settlements and buildings were digitised from the 'ZBGIS' maps (Geoportál, 2015), interpreted by polygon centroids and their frequency [n] was evaluated.

(iv) Potential natural vegetation: Potential natural vegetation (Miklós and Hrnčiarová, 2002) reflects geoclimatic and soil conditions and also the basic agronomic potential of the area. In the studied cadastral district, there is ascending altitude from south to the north, which is mirrored in the occurrence of different potential vegetation types. Carpathian oak-hornbeam forests potentially occur southernmost, sub-mountainous beech forests in the central part, and beech and fir-beech forests in the northern part (Fig. 1). We vectorised existing raster maps of potential natural vegetation and the vector maps were used for further analysis.

(v) Current land use: Based on the study of Agnoletti et al. (2015) from the Mediterranean region, terraces can be found both in areas of utilised agricultural land use and in forests and semi-natural areas.

The occurrence of terraces was analysed in agricultural and forest land use. Forest landscape was differentiated into general forests, which we designated as 'units of the spatial division of forests' (JPRL) and 'other wooded land' (OLP) (categorisation according to NFC, 2015). OLP is land not classified as "Forest", spanning more than 0.5 hectares, with trees higher than $5 \mathrm{~m}$ and a canopy cover of $5-10 \%$, or trees able to reach these thresholds in situ, or with a combined cover of shrubs, bushes and trees above $10 \%$. It does not include land that is predominantly under agricultural or urban land use (FAO, 2010). OLPs are characterised by the overgrowing of agricultural land with a forest which has arisen and significantly increased since the 1980s in Slovakia (Kurčíková, 2013). OLP units correspond with land covered by successive vegetation that has undergone the reforestation process and still has not been classified as a forest bearing productive and protective functions.

\subsection{Analysing the distribution of terraces and impacts of factors}

The MS Excel sheet prepared for the analysis had 3,200 rows, each representing one grid cell of the study area. In each row, there was one column with the terrace length and 12 columns representing the level or category of tested factors in the given grid cell.

To examine the correlations among the occurrence of terraces and tested factors, Spearman's rho-correlation coefficients were calculated. We applied statistical tools to identify significant relationship among geospatial variables in 3,200 squares of the study area. We assumed that positive autocorrelations between neighbouring squares appear but testing spatial dependency among variables was out of the scope of this article. However, identification of significant spatial clusters in the countryside would be realized in further work and enrich current research.

Linear regression was used to test the impact of continuous numeral factors (average slope, average altitude, distances of terraces from watercourses, settlements and buildings, units of land use and naturally potential vegetation). The null hypothesis tested was that the independent variables have no effect on terrace length. One-way ANOVA was used for the nominal category of historical county, with the two possible 
values of ' 1 ' or ' 0 ' in the analysis. The null hypothesis was that the terrace length is the same in both historic counties (Divín or Modrý Kameň). The nature of the impact (whether positive or negative) is provided by the variance explained by the regression model (indicated by the F-statistic), as well as the significance of the impact.

The relationships found between terrace length and the chosen factors, as well as among the factors themselves, were further visualised by the CANOCO programme using PCA ordination (principal component analysis). Originally, this program was developed and is used for the visualisation of ecological communities' composition of species and testing factors underlying these compositions. This research demonstrates other possible ways to apply this software in the field of environmental history, likewise enriching the landscape ecology. Using this software requires modification of the categorical variables entering the PCA analysis: each unit of the plot is analysed as one sample with 13 characteristics (first is the [dependable] terrace length in the specific unit, and the 12 other variables are the aforementioned tested factors): see Table 1.

\section{Results}

\subsection{Characteristics of the terraced landscape}

(i) The characteristics of the terrace spatial distribution: Terraces are most positively influenced by the natural environment, particularly by the geo-climatic gradient, approximated in the study by potential natural vegetation, but also by slope, water availability or land use. The highest density $\left(12.29 \mathrm{~km} / \mathrm{km}^{2}\right)$ was found in the Carpathian oakhornbeam forests. This unit exhibited the most favourable natural conditions for agriculture: the average altitude reached the lowest value and the average slope reached the second lowest value $\left(458 \mathrm{~m}\right.$ a.s.l. $\left./ 11.68^{\circ}\right)$ of any evaluated units. We found terrace walls covered by trees on historical maps of the second military mapping as well, as they were confirmed in the field (Fig. 2). Roots of trees strengthened terrace walls and improved the erosion control effectiveness of terraces. The lowest density was observed on the other hand in the sub-mountainous beech forests and beech-fir forests $\left(3.37 \mathrm{~km} / \mathrm{km}^{2}\right)$ in the northern part of the cadastral district (Tab. 2).

(ii) Testing effects of environmental factors on terraces by linear regression: Terraces were mostly built in sites of the Carpathian oak-hornbeam forests, where today agricultural land use predominates or in some places covered currently by so-called other wooded land (OLP). The occurrence of terraces is also positively correlated with increasing distance from buildings of settlements. The most significant negative relationship was observed among length of terraces and higher average altitude, and beech and fir-beech forests that are currently covered by production forests (JPRL). On the other hand, the negative relationship was significantly lower in areas with steeper slopes, increasing distance from watercourses and sub-mountainous beech forests (Tab. 3).

(iii) Differences in terraces distribution in the two historic counties: The density of terraces was significantly higher in Modrý Kameň County $\left(9.14 \mathrm{~km} / \mathrm{km}^{2}\right)$ than in Divín County $\left(4.40 \mathrm{~km} / \mathrm{km}^{2}\right)$. In comparison with Divín County, Modrý Kamen County's average altitude is lower, the plots have milder slope and the watercourses are closer. Up to the present, agricultural land use has a higher proportion here than in Divín County (Tab. 3).

\begin{tabular}{|c|c|c|c|c|}
\hline \multirow{2}{*}{ Factors } & \multicolumn{2}{|c|}{ Measurement of value } & \multirow{2}{*}{ Range of variation } & \multirow{2}{*}{ Unit of measurement } \\
\hline & Categorical & Continuous & & \\
\hline \multicolumn{5}{|l|}{ Historic units } \\
\hline - affiliation to the historic county of Divín & $\mathrm{X}$ & & 1 (yes) or 0 (no) & \\
\hline - affiliation to the historic county of Modrý Kameň & $\mathrm{X}$ & & 1 (yes) or 0 (no) & \\
\hline \multicolumn{5}{|l|}{ Limiting distances } \\
\hline - the distance from water & & $\mathrm{X}$ & $100-1,000$ & {$[\mathrm{~m}]$} \\
\hline - the distance from buildings and settlements & & $\mathrm{X}$ & $100-1,550$ & {$[\mathrm{~m}]$} \\
\hline \multicolumn{5}{|l|}{ Natural conditions } \\
\hline - the average altitude & & $\mathrm{X}$ & $348.10-816.10$ & [m a.s.l.] \\
\hline - the average slope & & $\mathrm{X}$ & $2.03-28.87$ & {$\left[{ }^{\circ}\right]$} \\
\hline $\begin{array}{l}\text { - naturally potential vegetation } \\
\text { 'Carpathian oak-hornbeam forests' }\end{array}$ & & $\mathrm{x}^{*}$ & $0-100$ & {$[\%]$} \\
\hline - naturally potential vegetation 'beech forests' & & $\mathrm{x}$ & $0-100$ & {$[\%]$} \\
\hline $\begin{array}{l}\text { - naturally potential vegetation } \\
\text { 'beech and fir-beech forests' }\end{array}$ & & $\mathrm{x}$ & $0-100$ & {$[\%]$} \\
\hline \multicolumn{5}{|l|}{ Current land use } \\
\hline - **current land use 'forests classified as JPRL' & & $\mathrm{x}$ & $0-100$ & {$[\%]$} \\
\hline - ***current land use 'forests classified as OLP' & & $\mathrm{x}$ & $0-100$ & {$[\%]$} \\
\hline - current land use 'agricultural land' & & $\mathrm{x}$ & $0-100$ & {$[\%]$} \\
\hline
\end{tabular}

Tab. 1: Characteristics of environmental factors influencing the distribution of agricultural terraces Source: authors' compilation and calculations

Notes: * The lower case ' $x$ ' represents a proportion from 100\%; ** JPRL - 'units of the spatial division of forests', OLP - 'other wooded land' (categorisation according to NFC, 2015); *** OLP land is the difference between land parcels, registered as JPRL and land parcels registered only as forests. OLP units correspond with agricultural land overgrown with a forest which still has not been classified as a forest bearing productive and protective functions. 


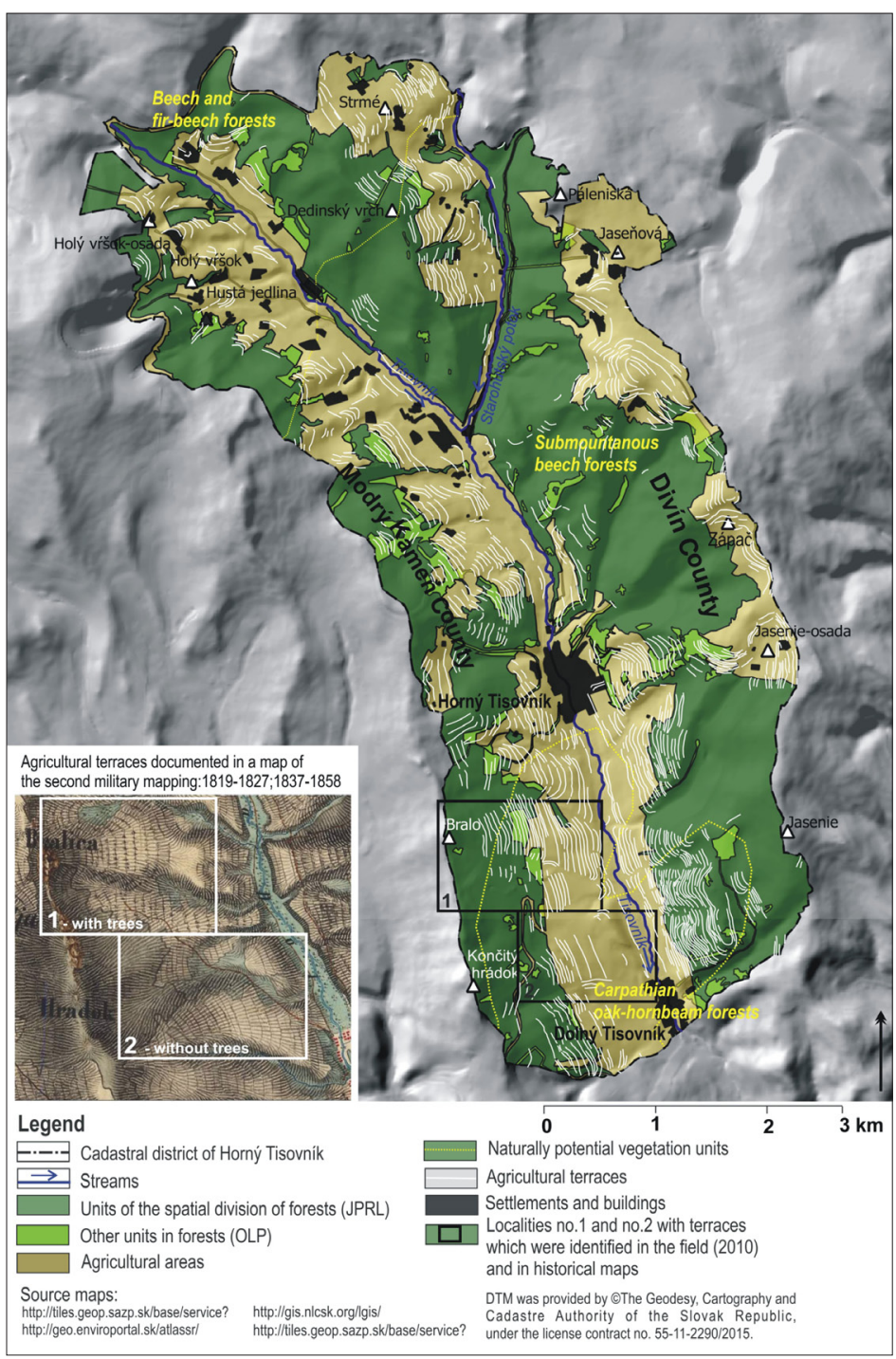

Fig. 2: Spatial distribution and types of terraces in the cadastral district of Horný Tisouník Source: authors' compilation

\begin{tabular}{|c|c|c|c|c|c|c|c|c|}
\hline \multirow{3}{*}{\multicolumn{2}{|c|}{ Geospatial parameters }} & \multicolumn{7}{|c|}{ Agricultural terraces in units of the cadastral district of Horný Tisovník } \\
\hline & & \multicolumn{2}{|c|}{$\begin{array}{l}\text { Length } \\
\text { of terraces }\end{array}$} & \multicolumn{2}{|c|}{ Area of units } & \multirow{2}{*}{$\begin{array}{c}\begin{array}{c}\text { Density } \\
\text { of terraces }\end{array} \\
{\left[\mathrm{km} / \mathrm{km}^{2}\right]}\end{array}$} & \multirow{2}{*}{$\begin{array}{c}\begin{array}{c}\text { Average } \\
\text { altitude } \\
\text { of terraces/ } \\
\text { units }\end{array} \\
\text { [m a.s.l. ] }\end{array}$} & \multirow{2}{*}{$\begin{array}{c}\begin{array}{c}\text { Average } \\
\text { slope } \\
\text { of terraces/ } \\
\text { units }\end{array} \\
\left.{ }^{\circ}\right]\end{array}$} \\
\hline & & {$[\mathrm{km}]$} & [\%] & {$\left[\mathrm{km}^{2}\right]$} & {$[\%]$} & & & \\
\hline \multicolumn{2}{|c|}{ Cadastral district } & 195.63 & 100.00 & 31.17 & 100.00 & 6.28 & $557 / 592$ & $13.67 / 14.09$ \\
\hline \multirow{3}{*}{$\begin{array}{l}\text { Current } \\
\text { land use }\end{array}$} & *Forests JPRL & 78.84 & 40.30 & 17.78 & 57.04 & 4.43 & $560 / 604$ & $15.38 / 12.92$ \\
\hline & $* * \mathrm{OLP}$ within forests & 17.79 & 9.09 & 1.98 & 6.35 & 8.98 & $581 / 584$ & $15.80 / 14.69$ \\
\hline & Agricultural land & 116.79 & 59.70 & 13.39 & 42.96 & 8.72 & $554 / 560$ & $12.49 / 11.06$ \\
\hline \multirow{3}{*}{$\begin{array}{l}\text { Potential } \\
\text { natural } \\
\text { vegetation }\end{array}$} & Carpathian oak-hornbeam forest & 61.10 & 31.23 & 4.98 & 15.98 & 12.27 & $460 / 458$ & $12.82 / 11.68$ \\
\hline & Sub-mountainous beech forests & 114.06 & 58.30 & 20.11 & 64.52 & 5.67 & $586 / 597$ & $14.13 / 14.57$ \\
\hline & Beech and fir-beech forests & 20.47 & 10.46 & 6.08 & 19.50 & 3.37 & $679 / 683$ & $13.58 / 14.48$ \\
\hline \multirow{2}{*}{$\begin{array}{l}\text { Historic } \\
\text { counties }\end{array}$} & Divín & 82.82 & 42.34 & 18.83 & 60.41 & 4.40 & $595 / 625$ & $14.14 / 14.63$ \\
\hline & Modrý Kameň & 112.81 & 57.66 & 12.34 & 39.59 & 9.14 & $504 / 542$ & $13.66 / 13.28$ \\
\hline
\end{tabular}

Tab. 2: The distribution of agricultural terraces in relation to environmental factors

Source: authors' calculations

Note: *JPRL - 'units of the spatial division of forests'; OLP -'other wooded land' (categorisation according to NFC, 2015); **OLP land is the difference between land parcels, registered as JPRL and land parcels registered only as forests 


\begin{tabular}{|c|c|c|c|c|c|c|c|}
\hline \multirow{3}{*}{ Factors (variables)* } & \multicolumn{4}{|c|}{ One-way ANOVA } & \multicolumn{3}{|c|}{ Linear regression } \\
\hline & \multicolumn{4}{|c|}{$\begin{array}{c}\text { Distribution of terraces expressed in length }[\mathrm{m}] \\
\text { as dependent variables; County as categorical } \\
\text { independent variable }\end{array}$} & \multicolumn{3}{|c|}{$\begin{array}{l}\text { Length }[\mathrm{m}] \text { is dependent variable } \\
\text { and the impact of various factors } \\
\text { (independent variables) on it is tested }\end{array}$} \\
\hline & $\begin{array}{l}\text { Divín County } \\
\quad(\text { mean })\end{array}$ & $\begin{array}{l}\text { Modrý Kameň } \\
\text { County (mean) }\end{array}$ & $\mathrm{F}$ & $\mathrm{p}$ & $\begin{array}{l}\text { Positive/negative } \\
\text { relationship }\end{array}$ & F & $\mathrm{p}$ \\
\hline Length of terraces & 56.2 & 64.9 & 3.1 & 0.047 & & & \\
\hline Carpathian oak - hornbeam forests & 14.0 & 16.5 & 2.0 & -- & + & 293.9 & $<0.0001$ \\
\hline Agricultural land use & 33.3 & 52 & 68.3 & $<0.001$ & + & 206.9 & $<0.0001$ \\
\hline $\begin{array}{l}\text { Distance of terraces from } \\
\text { settlements and building }\end{array}$ & 559.0 & 540.6 & 1.5 & -- & + & 79.1 & $<0.0001$ \\
\hline **OLP within forests & 5.5 & 6.8 & 2.7 & -- & + & 14.1 & 0.0002 \\
\hline Sub-mountainous beech forests & 61.4 & 59.1 & 1.6 & -- & - & 5.1 & 0.0234 \\
\hline Water distance & 428.8 & 387.6 & 6.7 & 0.0012 & - & 7.5 & 0.0062 \\
\hline Average slope & 14.4 & 13.4 & 16.2 & $<0.001$ & - & 11.9 & 0.0006 \\
\hline JPRL of forests & 59.5 & 44.0 & 45.2 & $<0.001$ & - & 101.2 & $<0.0001$ \\
\hline Beech and fir forests & 24.6 & 24.4 & 0.47 & -- & - & 131.3 & $<0.0001$ \\
\hline Average altitude (m a. s. l.) & 603.1 & 590.7 & 5.31 & 0.005 & - & 166.5 & $<0.0001$ \\
\hline
\end{tabular}

Tab. 3: Testing effects of environmental factors on terraces

Source: authors' calculations

Notes: *The list of variables is ordered according to the linear regression overall test statistic F; ** JPRL - 'units of the spatial division of forests'; OLP -'other wooded land' (categorisation according to NFC, 2015); F = value of F test statistic; $p=$ significance level (probability): $--=p>0.05$

\subsection{Correlations among the factors influencing terrace distribution: CANOCO visualisation}

Visualised correlations among the factors influencing terrace distribution in both counties (Divín and Modrý Kameň) indicated the existence of significant relationships between terrace distribution and some of examined factors. As we can see in the CANOCO visualisation (Figs. 3a and 3b), terraces in Divín County were situated not only in the Carpathian oak hornbeam forest, where agricultural land use prevails today, but also in the sub-mountainous beech forest, which is currently forested. They would occur on steeper slopes there. The first canonical axis explains $47.7 \%$ of the variance in the data, the second 43.6\%: together they explain $91.3 \%$ of the variance (3a).
In Modrý Kameň (3b) the terraces would predominantly be situated in the Carpathian oak hornbeam forests at lower altitudes on gentle slopes, where agricultural land prevails today. Their occurrence was negatively correlated with higher altitudes, steeper slopes, and, correspondingly with the unit of sub-mountainous beech and beech and fir forests and increasing distance from watercourses. The first canonical axis explains $72.5 \%$ of the variance in the data, the second $17.4 \%$ : together they explain $89.9 \%$ of the variance.

Divín and Modrý Kameň would not differ in the remaining factors - for example, the relative distribution of all types of potential vegetation was similar in both counties. There

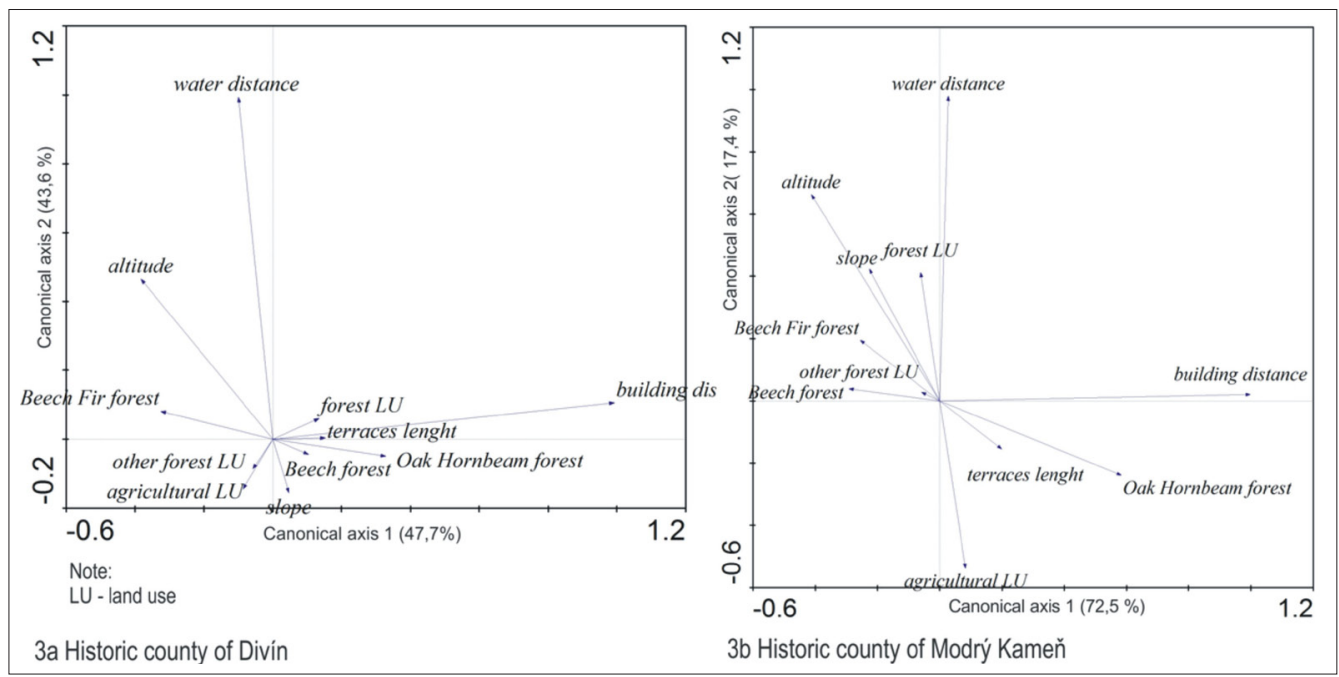

Fig. 3: Visualised correlations (CANOCO) among the factors influencing terrace distribution in both counties Divin (3a) and Modrý Kameň (3b) using the CANOCO ordination method (principal component analysis) Source: a uthors' calculations 
are other similarities as well: settlements are similarly dispersed in both counties, and the other wooded lands occur in similar percentages there.

Correlations among all tested factors are summarised in Table 4. Positive correlations, in general, exist among the increasing distance from watercourses, rising altitude, slope steepness, the units of natural potential vegetation represented by sub-mountainous beech forests and in higher altitude by beech and fir forests. In high altitude areas, the current land use consists of forests (JPRL and OLP within forests) and settlements and buildings. While the southernmost Carpathian oak-hornbeam forests comprised only 54 buildings and the single village of Dolný Tisovník, sub- mountainous beech forests comprised 365 buildings and the village of Horný Tisovník. Beech and beech-fir forests comprised 159 buildings, which were dispersed on the slopes, and no villages had developed there.
From the negative correlations, we see that the Carpathian oak-hornbeam forests and current agricultural land uses do not occur at higher altitudes, but near the watercourses and on gentle slopes. The negative correlation of decreasing watercourse distance and steep slopes shows that the steep slopes of the foothills of the valley, close to watercourses, were not used for agriculture. The current agricultural land use probably respects the traditional enclave that had developed in the lower elevations and also closer to the position of settlements and buildings (its area shrinks with the increasing distance from buildings and settlements).

\section{Discussion}

Economic growth and prosperity most often are at the expense of the natural environment. On the other hand, humans changed 'natural' landscapes into seminatural or cultural ones, and in the course of time these

\begin{tabular}{|c|c|c|c|c|c|c|c|c|c|c|c|c|c|}
\hline & & \multirow{2}{*}{ 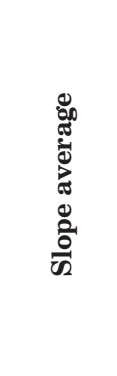 } & \multirow{2}{*}{ 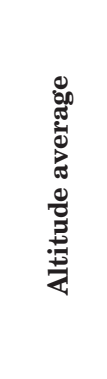 } & \multicolumn{2}{|c|}{ Historic county } & \multicolumn{3}{|c|}{$\begin{array}{c}\text { Potential vegetation units } \\
\text { forests } \\
\text { (\% of grid cell) }\end{array}$} & \multicolumn{3}{|c|}{$\begin{array}{l}\text { Current land use } \\
\text { (\% of grid cell) }\end{array}$} & \multirow{2}{*}{ 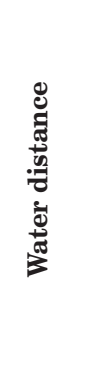 } & \multirow{2}{*}{ 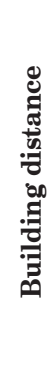 } \\
\hline & & & & 莒 & 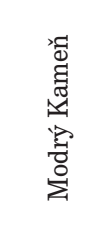 & 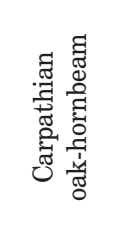 & 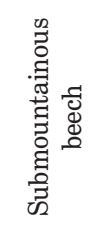 & 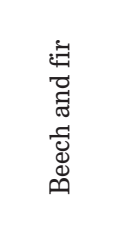 & 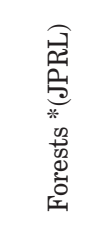 & 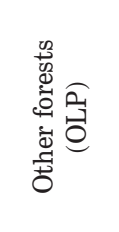 & 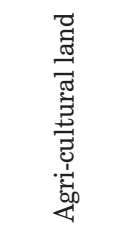 & & \\
\hline & & 1 & 2 & 3 & 4 & 5 & 6 & 7 & 8 & 9 & 10 & 11 & 12 \\
\hline \multirow[t]{2}{*}{1} & $\mathrm{r}$ & & & & & & & & & & & & \\
\hline & $\mathrm{p}$ & & & & & & & & & & & & \\
\hline \multirow[t]{2}{*}{2} & $\mathrm{r}$ & 0.2039 & & & & & & & & & & & \\
\hline & $\mathrm{p}$ & 0.0001 & & & & & & & & & & & \\
\hline \multirow[t]{2}{*}{3} & $\mathrm{r}$ & 0.0641 & 0.1588 & & & & & & & & & & \\
\hline & $\mathrm{p}$ & 0.0002 & 0.0001 & & & & & & & & & & \\
\hline \multirow[t]{2}{*}{4} & $\mathrm{r}$ & -0.154 & -0.2582 & -0.9126 & & & & & & & & & \\
\hline & $\mathrm{p}$ & 0.0001 & 0.0001 & 0.0001 & & & & & & & & & \\
\hline \multirow[t]{2}{*}{5} & $\mathrm{r}$ & -0.2089 & -0.5229 & -0.2729 & 0.2832 & & & & & & & & \\
\hline & $\mathrm{p}$ & 0.0001 & 0.0001 & 0.0001 & 0.0001 & & & & & & & & \\
\hline \multirow[t]{2}{*}{6} & $\mathrm{r}$ & 0.1467 & -0.0495 & 0.2653 & -0.2733 & -0.5228 & & & & & & & \\
\hline & $\mathrm{p}$ & 0.0001 & 0.0046 & 0.0001 & 0.0001 & 0.0001 & & & & & & & \\
\hline \multirow[t]{2}{*}{7} & $\mathrm{r}$ & 0.0089 & 0.496 & -0.0721 & 0.0725 & -0.2466 & -0.6972 & & & & & & \\
\hline & $\mathrm{p}$ & & 0.0001 & 0.0001 & 0.0001 & 0.0001 & 0.0001 & & & & & & \\
\hline \multirow[t]{2}{*}{8} & $\mathrm{r}$ & 0.5589 & 0.1574 & 0.1639 & -0.2295 & -0.0807 & 0.1719 & -0.1275 & & & & & \\
\hline & $\mathrm{p}$ & 0.0001 & 0.0001 & 0.0001 & 0.0001 & 0.0001 & 0.0001 & 0.0001 & & & & & \\
\hline \multirow[t]{2}{*}{9} & $\mathrm{r}$ & 0.0932 & -0.0184 & -0.0195 & 0.0079 & -0.0264 & 0.0419 & -0.0255 & 0.1977 & & & & \\
\hline & $\mathrm{p}$ & 0.0001 & & & & & 0.0163 & & 0.0001 & & & & \\
\hline \multirow[t]{2}{*}{10} & $\mathrm{r}$ & -0.5324 & -0.2736 & -0.1546 & 0.2301 & 0.1347 & -0.0545 & -0.0513 & -0.8997 & -0.1625 & & & \\
\hline & $\mathrm{p}$ & 0.0001 & 0.0001 & 0.0001 & 0.0001 & 0.0001 & 0.0018 & 0.0033 & 0.0001 & 0.0001 & & & \\
\hline \multirow[t]{2}{*}{11} & $\mathrm{r}$ & -0.0547 & 0.4782 & 0.2822 & -0.3611 & -0.1646 & 0.0678 & 0.0613 & 0.1386 & -0.0615 & -0.2233 & & \\
\hline & $\mathrm{p}$ & 0.0017 & 0.0001 & 0.0001 & 0.0001 & 0.0001 & 0.0001 & 0.0004 & 0.0001 & 0.0004 & 0.0001 & & \\
\hline \multirow[t]{2}{*}{12} & $\mathrm{r}$ & -0.0621 & -0.337 & 0.0128 & -0.0212 & 0.4063 & -0.0602 & -0.2733 & 0.0697 & -0.0619 & -0.0373 & 0.0159 & \\
\hline & $\mathrm{p}$ & 0.0004 & 0.0001 & & & 0.0001 & 0.0006 & 0.0001 & 0.0001 & 0.0004 & 0.0329 & & \\
\hline
\end{tabular}

Tab. 4: Summary table of correlations among the factors influencing terrace distribution

Source: authors' calculations

Note: * JPRL - 'units of the spatial division of forests'; OLP -'other wooded land' (categorisation according to NFC, 2015); $p$-value is not shown, where $p>0.05$ 
acquired an intrinsic value. It is often said that knowledge of environmental history is a prerequisite for future management (Nienhuis, 2008). The sources from which environmental history is to be written can and must themselves be placed into the interaction model to connect it to the critical method that lies behind every truth-claiming statement about the past (Hoffman, 2014). This article comprises a basic evaluation of the density of terraces and brings new insights into the environmental factors influencing the foundation of the terraces, as well as partially indicated reasons for their current abandonment.

The basic attributes of the terraces: length $(195.6 \mathrm{~km})$ and density $\left(6.3 \mathrm{~km} / \mathrm{km}^{2}\right)$ were worth considering in the cadastral district of Horný Tisovník for this particular research. In comparison, Swiechovicz (2002) indicated the density of terraces within the range from $0.8 \mathrm{~km} /$ $\mathrm{km}^{2}$ to $1.0 \mathrm{~km} / \mathrm{km}^{2}$ in a similar Carpathian sub-mountain agricultural landscape in the water catchment area of Stara Rzeka in Poland. In Italy, Agnoletti et al. (2015) reported a high density of terraces in the Mediterranean Tuscany region $\left(40 \mathrm{~km} / \mathrm{km}^{2}\right)$, where terraces occur more frequently than in Carpathian countries. The comparison of a terrace density among similar agricultural landscapes, however, is problematic due to several reasons as noted by Varotto and Ferrarese (2008). The quality of scientific evidence crucially depends on the technical and technological equipment used for data acquisition and their further applications in different research areas (Chudy et al., 2014). In the case of the study area, the accuracy of terrace data could be improved. Currently, we use the DTM 3.5 which represents a corrected DTM 3 that had a hypsographic accuracy $\pm 2.5 \mathrm{~m}$ (locally worse) (Geoportál, 2015). Thus, an application of light detection and ranging scanners, professional global satellite navigation systems or photogrammetric methods has become a challenge for our future research.

Every landscape has a unique history and distinct characteristics. Landscape history shows complex and many-sided histories, indicating periods of relative stability alternating with periods of transformations (Renes, 2015). Our findings led us to the conclusion that the parallel existence of different feudal management systems implied the evolution of the specific 'agriculturally industrial' type of cultural landscape in the cadastral district.

A significantly greater amount of terraces was found in Modrý Kameň County than in Divín. These counties differed also in the average levels of some factors. For example, the current land use in Divín today is predominantly forest, while in Modrý Kameň it is agricultural land. This might be connected with the overall features of the landscape in the counties. Divín lies at a higher altitude and its plots have an on-average steeper slope, while the plots of Modrý Kameň are closer to water streams. Altitude exhibited negative correlations with terraces in all cases. Therefore, we can sustain the statement by Dobrovodská (2006) that it is a limiting factor for agriculture in the Carpathian Mountains. The terraces' length positively correlated with steeper slopes in Divín County, where wood-processing, industrial and pastoral activities prevailed.

The primary reason for the expansion of agricultural terraces, beginning in the $16^{\text {th }}$ century, was industrial growth. Intensive agricultural activity initiated erosion processes, which were reported in archival materials. Alberty et al. (1989) documented, moreover, the relocation of washed-up soil from the cultivated fields and transportation back by animal carriages or manually by inhabitants in wicker baskets in the study area. Midriak (2008) observed the average intensity of water erosion processes in the study area; $15 \mathrm{~m}^{3} \cdot \mathrm{ha}^{1} \cdot \mathrm{yr}^{-1}\left(1.5 \mathrm{~mm} \cdot \mathrm{yr}^{-1}\right)$ on the deforested land (previous 100-150 years) on andesitic rocks (580-675 $\mathrm{m}$ a.s.l.). These findings correspond with official standards and limits on permitted soil erosion rates declared in the executive regulation No. 59/2013 on Land Use and Protection (Ministry of Agriculture and Rural Development of the Slovak Republic, 2013). Panagos et al. (2015), however, within the frame of conservation practices on steep slopes, recommended the application of policy instruments of Good Agricultural Environmental Conditions to all Member States implementing contour farming in slopes of less than $10 \%$ $\left(5.72^{\circ}\right)$. Stone walls and grass margins positively affect reductions in soil loss, as reported by Panagos et al. (2015). Slope steepness of more than $11^{\circ}$ was observed to be one of the essential and conditional factors determining terrace preservation in current land use (Lieskovský et al., 2014) in Slovakia. These investigations correspond with our results. Terraces were preserved in agricultural land use with an average slope of $11^{\circ}$ up to the present and have to be retained in the future.

On the other hand, nearly half of the terrace length within JPRL (17.78 km²) and OLP (1.98 km²) (78.84 km; 40.30\%) was covered by forests due to recent natural succession processes in the cadastral district. In Italy, Agnoletti et al. (2011) presented similar results on progressive rural area abandonment in the Lamole study area (Italy), where they documented around $40 \%$ of the terracing lost in only fifty years, and $10 \%$ of those still remaining are affected by secondary successions following the abandonment of farming activities. The vanishing of traditional landscapes with its typical features (farming terraces, olive yards, and upland grasslands, etc.) is a phenomenon in many European countries. It has been recorded over the past 50 years in many Mediterranean countries (Sluis et al., 2014; Agnoletti, 2014; Petanidou et al., 2008), some countries in Western Europe (Garzía-Ruiz and Lana-Renault, 2011) and without doubt in former Soviet Union countries, as well as in the case of Slovakia (Lieskovský et al., 2015). Corresponding to findings of previous authors, we have also confirmed terrace abandonment in the cadastral district of Horný Tisovník.

Although we observed a negative relationship between terrace distribution and distance from buildings within the cadastral district, the factor of the terraces' availability should be considered when future terrace management is planned, as pointed out by Lieskovský et al. (2015). Further, we expected that terraces would be predominantly built in the vicinity of water resources. Correlations of distances between terraces and watercourses, however, did not show any significant associations. Therefore, correlations of distances between terraces and watercourses should also be enriched by the distances of terraces from water springs. Water springs data were not available for this research and the analysis should be repeated including this information in the future.

The distribution of terraces is correlated positively with Carpathian oak-hornbeam forests and lower altitudes. Natural conditions in this forest unit were the most suitable for agricultural activities in the past. Therefore, we expected that colonisation started from the southern part of the cadastral district. The Carpathian oakhornbeam forests predominantly cover intra-mountain basins and the foothills of mountains in Slovakia. This 
unit covers $11,907.51 \mathrm{~km}^{2}$ (24.28\%) (data from the Atlas of the Slovak Republic, Miklós and Hrčiarová, 2002) of the total territory of Slovakia $\left(49,035 \mathrm{~km}^{2}\right)$ and it is relatively less represented in the study area (15.98\%). No survey has been carried out to examine the positive relationship between terraces and the Carpathian oak-hornbeam forests in Slovakia. Therefore, on the basis of our results, such research is required in the near future.

\section{Conclusions}

Ordination methods are frequently used in biogeographic studies. Later, multivariate statistics gradually spread into landscape ecology research, and this article represents their broader application in the field of environmental history.

We observed evident differences in terrace distribution within both historical territories governed by different feudal economic systems with different natural conditions. Significantly, a greater amount of terraces was found in Modrý Kameň County than in Divín. These counties differed also in the average levels of some factors. For example, the current land use in Divín today is predominantly forest, while in Modrý Kameň it is agricultural land. This might be connected with the overall landscape features: Divín lies at a higher altitude and its plots have on-average steeper slopes, while the plots of Modrý Kameň are closer to water streams.

With respect to natural conditions, we found that terraces are most positively influenced by the ecological potential of the area. They were mostly built in sites of the Carpathian oak-hornbeam forests, where today agricultural land use predominates or in some places covered currently by socalled other wooded lands (OLP). Carpathian oak-hornbeam forests comprise the unit, natural conditions were the most suitable for agricultural activities in the past, and where actively used agricultural land persists today. On the other hand, terraces were significantly less represented in areas with higher altitudes, greater slopes, plots at greater distances from watercourses, and those within the unit of potential natural vegetation of Sub-mountain Beech forests and Beech-Fir forests that are currently covered by the production forests (JPRL).

Agricultural terraces were historically built also in the sites currently classified as OLP, on slopes steeper than the average slope of the evaluated terraces. Most likely due to steep slopes, terraces here were abandoned and reforested. It is interesting that the distribution of the OLP units within forests, which occurred similarly in both historic counties, indicated that land abandonment phenomena do not depend on the historic economic systems of the counties. The density of terraces in the OLP was comparable with the density of agricultural land use, due to the steep slopes of terraces within these units that were reforested. The overgrown land of OLP should be re-cultivated back to agricultural land or converted to forest land to avoid irregularities in the real estate register (Kurčíková, 2013).

The current situation of land use in agricultural landscapes allows us to recommend a management plan in terms of multifunctional landscapes. The results of this research project have three implications for future landscape planning:

1. Terraces played a fundamental erosion role in reducing soil loss in the past. In any case, they have to be protected in the agricultural landscape on the basis of incentives proposed within land consolidation projects;
2. The OLPs within forests, where the steepest terraced slopes were found, are expected to be delimited to the JPRL units meeting an appropriate functional use of future forests (production and protective functions). The effectiveness of forest services should be reinforced by the forest management plans; and

3. Terraced landscapes, which meet cultural and natural values, are a potential and interesting resource for the development of mountain areas (Lasanta et al., 2013). Spatial planning documentations are considered to be alternative comprehensive instruments to other plans for the area of development strategies, coordinating multisectoral activities within the territory. Inclusion of landscape values into spatial plans introduces an opportunity to promote local identities and to support landscape quality. The conservation of the cultural features of agricultural landscapes can add value to tourism and provide local and regional food products. Preserved rural landscapes also help maintain the quality of life for rural residents by providing viable communities and economies and the positive values associated such landscapes (Agnoletti, 2014).

\section{Acknowledgements}

This paper was financially supported by the Visegrad International Fund (Co. No. 51500282): Jana Krčmářová, project 'Identifying traces of traditional management in the current landscape'; and by GA $\check{C} R$ (project No. 1615716S) 'Czech agricultural revolution of $19^{\text {th }}$ century in the perspective of microhistory and ecological anthropology'.

\section{References}

AGNOLETTI, M., CARGNELLO, G., GARDIN, L., SANTORO, A., BAZZOFFI, P., SANSONE, L., PEZZA, L., BELFIORE, N. (2011): Traditional Landscape and Rural Development: Comparative Study in three Terraced Areas in Northern, Central and Southern Italy to Evaluate The Efficacy of GAEC Standard 4.4 of Cross Compliance. Italian Journal of Agronomy, 6(s1), e16: 121-139.

AGNOLETTI, M. (2014): Rural Landscape, Nature Conservation and Culture: Some Notes on Research Trends and Management Approaches from a (Southern) European Perspective. Landscape and Urban Planning, 126: 66-73.

AGNOLETTI, M., CONTI, L., FREZZA, L., SANTORO, A. (2015): Territorial Analysis of the Agricultural Terraced Landscapes of Tuscany (Italy): Preliminary Results. Sustainability 15(7): 4564-4581.

ALBERTY, J. OŽDÁNI, O., SÁSKY, L., TOČÍK, A. (1989): Novohrad-dejiny. Martin, Osveta.

ALTIERI, M. (1999): The Ecological Role of Biodiversity in Agroecosystems. Agriculture, Ecosystems and Environment, 74: 19-31.

BALASA, G. (1960): Praveké osídlenie stredného Slovenska. Martin, Osveta.

BEVAN, A., CONOLLY, J., COLLEDGE, S. FREDERICK, C., PALMER, C., SIDDALL, R., STELLATOU, A. (2013): The Long-Term Ecology of Agricultural Terraces and Enclosed Fields from Antikythera, Greece. Human Ecology, 41: 255-272. 
BOROVSZKY, S. [ed.] (1911): Magyarország Vármegyéi és Városai - Nógrád Vármegye. Országos Monografia Társaság, Budapest.

CHUDY F., SADIBOL, J., SLAMOVA, M., BELACEK, B., BELJAK PAZINOVA, N., BELJAK, J. (2014): Identification of Historic Roads in the Forest Landscape by Modern Contactless Methods of Large-scale Mapping. GeoConference on informatics, geoinformatics and remote sensing: Conference proceedings. Sofia: STEF92 Technology, 3: 184-190.

COUNCIL OF EUROPE (CoE) (2000): The European Landscape Convention [online]. [cit. 0.05.2011]. ETS No. 176, Strasbourg. Available at: http://www.coe. int/t/dg4/cultureheritage/heritage/Landscape/default_ en.asp

DE BLOIS, S., DOMON, G., BOUCHARD, A. (2001): Environmental, historical, and contextual determinants of vegetation cover: a landscape perspective. Landscape Ecology, 16: 421-436.

DOBROVODSKÁ, M. (2006): The Development of Relations between Man and Landscape in a Historical Mountain Agricultural Landscape of Slovakia. Ekológia (Bratislava), 25(1): 38-48.

ERICSON, C. L. (2003): Agricultural Landscapes as World Heritage: Raised Field Agriculture in Bolivia and Peru. In: Teutonico, J. M., Matero, F. G. [eds.]: Managing Change: Sustainable Approaches to the Conservation of the Built Environment (pp. 181-204). Los Angeles, Conservation Institute.

FALL， P. L., FALCONER， S. E., GALLETTI， C. S., SHIRMANG, T., RIDDER, E., KLINGE, J. (2012): Long-term Agrarian Landscapes in the Troodos Foothills, Cyprus. Journal of Archaeological Science, 39: 2335-2347.

FOOD AND AGRICULTURE ORGANIZATION OF THE UNITED NATIONS (FAO), FORESTRY DEPARTMENT (2010): Global Forest Resources Assessment 2010, Country Report, Slovakia [online]. [cit. 12.09.2016]. Forestry Department at FAO headquarters in Rome Available at: http://www.fao.org/docrep/013/al626E/ al626e.pdf

GARZÍA-RUIZ， J. M., LANA-RENAULT, N. (2011): Hydrological and Erosive Consequences of Farmland Abandonment in Europe, with Special Reference to the Mediterranean Region - A Review. Agriculture, Ecosystems \& Environment, 140(3-4): 317-338.

GEOPORTÁL (2015): ZBGIS Map Client [online]. [cit. 15.05.2015]. Geodetic and Cartographic Institute, Bratislava. Available at: https://zbgis.skgeodesy.sk/tkgis/ default.aspx?lang $=\mathrm{en} /$

HOFFMAN, R. (2014): An Environmental History of Medieval Europe. Cambridge, Cambridge University Press.

HOLEC, R. (2014): Človek a príroda v "dlhom” 19. storočí. Bratislava, Historický ústav SAV v Bratislave.

HORŇÁK, M., ROCHOVSKÁ, A. (2007): Selected Quality Life Aspects in Inner Peripheries of Slovakia. Geographia Cassoviensis, 1: 55-60.

HREŠKO, J., KANASOVÁ, D., PETROVIČ, F. (2010): Landscape archetypes as the elements of Slovak historical landscape structure. Ekológia (Bratislava), 29(2): 158-173.

HRONČEK, P. (2014): Environmental history of the landscape. A case study of Brusno. Banská Bystrica, Faculty of Natural Sciences, Matej Bel University in Banská Bystrica.

KURČÍKOVÁ, M. (2013): Identifikácia hraníc a charakteristík bielych plôch s využitím údajov DPZ. In GIS Ostrava 2013: symposium, 21.-23. ledna 2013. [online]. [cit. 15.05.2015]. Ostrava, Institut geoinformatiky. Available at: http://gisak.vsb.cz/GIS_Ostrava/GIS_Ova_2013/ sbornik/papers/gis2013508a4f11a7687.pdf

LASANTA, T., ARNAEZ, J., RUIZ FLANO, P., LANARENAULT MONREAL, N. (2013): Agricultural terraces in the Spanish Mountains: an abandoned landscape and a potential resource. Boletin de la Asociacion de Geografos Espanoles, 63: 487-491.

LEWIS, M. (2014): And All Was Light? Science and Environmental History. In: Isenberg, A. C. [ed.]: The Oxford Handbook of Environmental History (pp. 207-227). Oxford University Press.

LIESKOVSKÝ J., KENDERESSY P., ŠPULEROVÁ J., LIESKOVSKY T., KOLEDA P., KIENAST F., GIMMI U. (2014): Factors affecting the persistence of traditional agricultural landscapes in Slovakia during the collectivization of agriculture. Landscape Ecology 29: 867-877.

LIESKOVSKÝ, J., BEZÁK, P., ŠPULEROVÁ, J., LIESKOVSKÝ, T., KOLEDA, P., DOBROVODSKÁ, M., BÜRGI, M., GIMMI, U. (2015): The Abandonment of Traditional Agricultural Landscape in Slovakia - Analysis of Extent and Driving Forces. Journal of Rural Studies, 37: 75-84.

MARTULIAK, P. (2006): Cez Tisovník vybíjaný chodník... Horný a Dolný Tisovník v minulosti a dnes. Banská Bystrica, Trian.

McCANE, C., MACRAE, S., IANNONE, G. (2010): A Consideration of the Spatial Arrangement of Settlement Groups and Terraces in Contreras, Minanha, Belize. Research Reports in Belizean Archaeology, 7: 41-52.

MIDRIAK, R. (2008): Badlands in Slovakia as an indicator of non-rational using of the landscape. In: Nováková, M., Sviček, M. [eds.]: Environmental aspects of the landscape's analysis and evaluation Identification and indicators (and indexes) on the basis of the field survey and remote sensing data (pp. 46-53). Proceedings of the scientific seminar. Bratislava, VUPOP.

MIKLÓS, L., HRNČIAROVÁ, T. [eds.] (2002): Landscape Atlas of the Slovak Republic. Bratislava, MŽP SR and SAŽP.

MINISTRY OF AGRICULTURE AND RURAL DEVELOPMENT OF THE SLOVAK REPUBLIC (2013): Executive Regulation No. 59/2013 on Land Use and Protection [online]. [cit. 06.06.2016]. Available at: http:// www.noveaspi.sk/products/lawText/1/79667/1/2

NATIONAL FOREST CENTRE OF THE SLOVAK REPUBLIC (NFC) (2015): Forest Geographical Information System [online]. [cit. 15.05.2015]. NFC, Zvolen. Available at: http://gis.nlcsk.org/lgis/

NIENHUIS, P. H. (2008): Environmental History of the Rhine-Meuse Delta. Netherlands, Springer. 
PANAGOS, P., BORRELLI, P., MEUSBURGER, K., VAN DER ZANDEN, E. H., POESEN, J., ALEWELL, C. (2015): Modelling the effect of support practices (P-factor) on the reduction of soil erosion by water at European scale. Environmental Science \& Policy, 51: $23-34$.

PETANIDOU, T., KIZOS, T., SOULAKELLIS, N. (2008): Socioeconomic Dimensions of Changes in the Agricultural Landscape of the Mediterranean Basin: A Case Study of the Abandonment of Cultivation Terraces on Nisyros Island, Greece. Environmental Management, 41: $250-266$.

QUINTUS, S., CLARK, J. T., DAY, S. S., SCHWERT, D. P. (2015): Investigating regional patterning in archaeological remains by pairing extensive survey with a Lidar dataset: The case of the Manu'a Group, American Samoa. Journal of Archaeological Science: Reports, 2: 677-687.

RENES, H. (2015): Historic Landscapes without History? A Reconsideration of the Concept of Traditional Landscapes. Rural Landscapes: Society, Environment, History, 2(1): 1-11.

ROLÉ, A. (2007): The Terraced Landscapes of the Maltese Islands. In: Pedroli B., Van Doorn, A., De Blust, G., Paracchini, M. L., Wascher, D., Bunce, F. [eds.]: Europe's Living Landscapes. Essays on Exploring our Identity in the Countryside. Landscape Europe (pp. 406-420). The Netherlands, KNNV Publishing.

SLÁMOVÁ, M., JANČURA, P., DANIŠ, D. (2013): Methods of historical landscape structures identification and implementation into landscape studies. Ekológia Bratislava, 32(3): 267-276.

SLOVAK ENVIRONMENTAL AGENCY (SEA) (2015): Base maps [online]. [cit. 04.03.2016]. Available at: http:/tiles. geop.sazp.sk/base/service?

SLUIS, T. VAN DER, KIZOS, T., PEDROLI, B. (2014): Landscape Change in Mediterranean Farmlands: Impacts of Land Abandonment on Cultivation Terraces in Portofino (Italy) and Lesvos (Greece). Journal of Landscape Ecology, 7(1): 23-44.
ŠPULEROVÁ, J., PETROVIČ, F. (2011): Historical Agricultural Landscape as a Subject of Landscape Ecological Research. Hrvatski Geografski Glasnik, 73(2): 155-163.

ŠPULEROVÁ, J., DOBROVODSKÁ, M., ŠTEFUNKOVÁ, D., PISCOVÁ, V., PETROVIČ, F. (2014): Evolution of the Traditional Agricultural Landscape of Slovakia. In: Efe, R., Ozturk, M. [eds.]: Environment and Ecology in Mediterranean Region II (pp. 133-146). Newcastle upon Tyne, Cambridge Scholars Publishing.

STANCHI, S., FREPPAZ, M., AGNELLI, A., REINSCH, T., ZANINI, E. (2012): Properties, Best Management Practices and Conservation of Terraced Soils in Southern Europe (from Mediterranean Areas to the Alps): A Review. Quaternary International, 265: 90-100.

STANKOVIANSKY, M. (2001): Tillage erosion and its geomorphic effect with special regard to the MyjavaWhite Carpathian kopanitse area. Geografický časopis, 53(2): 95-110.

STATISTICAL DISCOVERY SOFTWARE (SAS) (2015): JMP 7.0.1 TM for Windows [online]. [cit. 20.11.2015]. SAS Campus Drive, Cary, NC, USA. Available at: http:// www.jmp.com/en_us/home.html

SWIECHOVICZ, J. (2002): The influence of plant cover and land use on the slope-channel decoupling in a foothill catchment: a case study from the Carpathian Foothills, Southern Poland. Earth Surface Processes and Landforms, 27: 463-479.

TER BRAAK, C. J. F., ŠMILAUER, P. (2003): CANOCO - A FORTRAN Program for canonical community ordination by [partial] [detrended] [canonical] correspondence analysis, principal component analysis and redundancy analysis, Version 4.5. Wageningen, The Netherlands.

VAROTTO, M., FERRARESE, F. (2008): Mapping and Geographical Classification of Terraced Landscapes: Problems and Proposals. Terraced Landscapes of The Alps. Atlas. Marsilio, (pp. 38-45). [Online]. [Cit. 04.03.2016]. Available at: http://www.alpter.net/img/pdf/ alpter_atlas_eng_small.pdf

Please cite this article as:

SLÁMOVÁ, M., KRČMÁŘOVÁ, J., HRONČEK, P., KAŠTIEROVÁ, M. (2017): Environmental factors influencing the distribution of agricultural terraces: Case study of Horný Tisovník, Slovakia. Moravian Geographical Reports, 25(1): 34-45. Doi: 10.1515/mgr-2017-0004. 